USAWC STRATEGY RESEARCH PROJECT

\title{
UNITED STATES NATIONAL SPACE SECURITY POLICY AND THE STRATEGIC ISSUES FOR DOD SPACE CONTROL
}

\author{
by \\ Lieutenant Colonel Maurice Perdomo \\ United States Marine Corps Reserve
}

\author{
Professor William Pierce \\ Project Adviser
}

\begin{abstract}
This SRP is submitted in partial fulfillment of the requirements of the Master of Strategic Studies Degree. The U.S. Army War College is accredited by the Commission on Higher Education of the Middle States Association of Colleges and Schools, 3624 Market Street, Philadelphia, PA 19104, (215) 662-5606. The Commission on Higher Education is an institutional accrediting agency recognized by the U.S. Secretary of Education and the Council for Higher Education Accreditation.

The views expressed in this student academic research paper are those of the author and do not reflect the official policy or position of the Department of the Army, Department of Defense, or the U.S. Government.
\end{abstract}

U.S. Army War College

CARLISLE BARRACKS, PENNSYLVANIA 17013 


\section{Report Documentation Page}

Form Approved

OMB No. 0704-0188

Public reporting burden for the collection of information is estimated to average 1 hour per response, including the time for reviewing instructions, searching existing data sources, gathering and maintaining the data needed, and completing and reviewing the collection of information. Send comments regarding this burden estimate or any other aspect of this collection of information,

including suggestions for reducing this burden, to Washington Headquarters Services, Directorate for Information Operations and Reports, 1215 Jefferson Davis Highway, Suite 1204, Arlington

VA 22202-4302. Respondents should be aware that notwithstanding any other provision of law, no person shall be subject to a penalty for failing to comply with a collection of information if it

does not display a currently valid OMB control number.

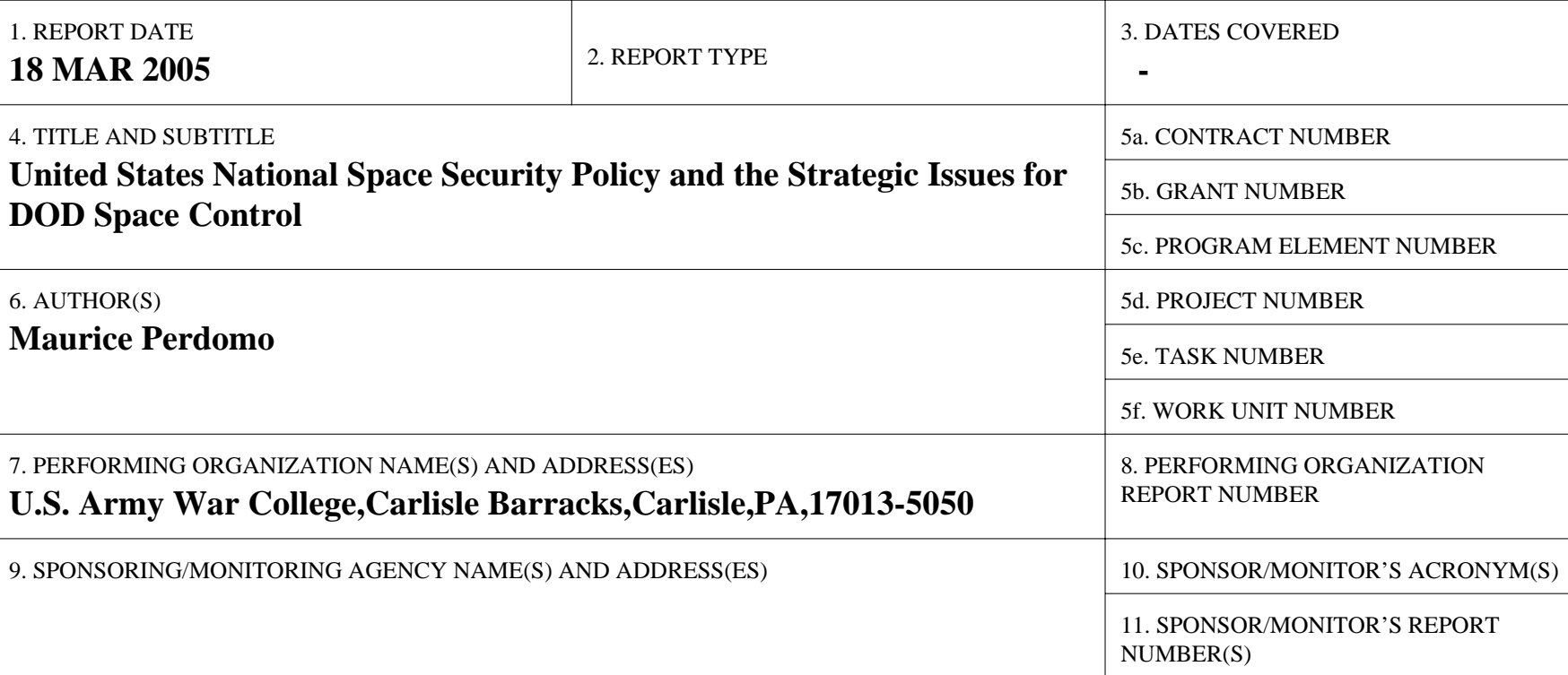

12. DISTRIBUTION/AVAILABILITY STATEMENT

Approved for public release; distribution unlimited

13. SUPPLEMENTARY NOTES

14. ABSTRACT

See attached.

15. SUBJECT TERMS

16. SECURITY CLASSIFICATION OF:

a. REPORT

unclassified b. ABSTRACT

unclassified c. THIS PAGE

unclassified
17. LIMITATION OF ABSTRACT

\begin{tabular}{|l|l|}
\hline $\begin{array}{c}\text { 18. NUMBER } \\
\text { OF PAGES } \\
\mathbf{2 9}\end{array}$ & 19a. NAME OF \\
& \\
&
\end{tabular}




\section{ABSTRACT}

AUTHOR: Lieutenant Colonel Maurice Perdomo

TITLE: $\quad$ United States National Space Security Policy and the Strategic Issues for DoD Space Control

FORMAT: Strategy Research Project

DATE: 18 March 2005 PAGES: 29 CLASSIFICATION: Unclassified

The United States has been the world leader in space for decades and is second to none in the development of space technology and its uses for industrial, civil, military, and intelligence operations. However, the rest of the world is increasing its reliance on space applications such as navigation, communications, weather prediction, agriculture, and urban planning. The list of how space technology contributes to the world economy grows almost daily. Space globalization is racing faster than U.S. National Security Strategy can keep up. The U.S. Strategy calls for the military to develop capabilities to protect U.S. assets in outer space. This is to ensure the use of space assets during time of conflict. Potential adversaries understand the vulnerabilities. America must deny the enemy use of space if called upon to do so and ensure its ability to operate freely.

Space Control actions will increasingly encounter strategic issues as adversaries use third party space assets to enhance their military and intelligence operations. What are the implications for military and national security planners when third party space assets and services are interwoven into an adversary's capabilities? Will current U.S. space policy meet the needs of the nation in an era of space globalization? To answer these questions this paper will review the national and military policies on space. It will also summarize the effects of space globalization, to include the world's increasing reliance on civilian space assets. Finally, a strategic analysis of space control policies and doctrine will determine if there is a sound space strategy in the face of globalization and if not, suggest recommendations for possible action. 
TABLE OF CONTENTS

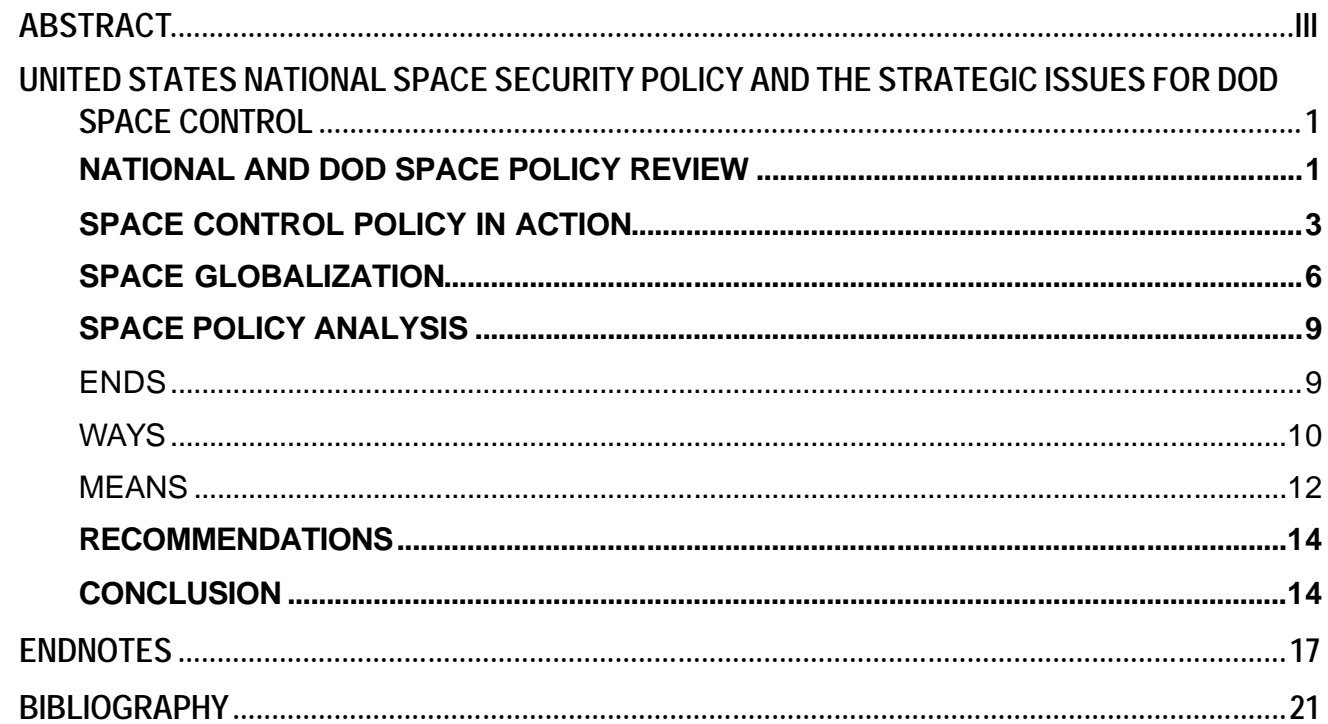




\section{UNITED STATES NATIONAL SPACE SECURITY POLICY AND THE STRATEGIC ISSUES FOR DOD SPACE CONTROL}

The United States has been the world leader in space for decades and is second to none

in the development of space technology and its uses for industrial, civil, military, and intelligence operations. However, the rest of the world is increasing its reliance on space applications such as navigation, communications, weather prediction, agriculture, and urban planning. The list of how space technology contributes to the world economy grows almost daily. Space globalization is a phenomenon that our National Military Strategy must consider. The National Security Strategy calls for the military to develop capabilities to protect U.S. assets in outer space. This is to ensure the use of space assets during time of conflict. Potential adversaries understand the U.S. reliance on space systems and their vulnerabilities. The U.S. must deny the adversary use of space if called upon to do so and ensure the ability to operate freely.

The space community will increasingly encounter strategic issues as adversaries use third party space assets to enhance their military and intelligence operations. What are the implications for military and national security planners when third party space assets and services are interwoven into our adversary's capabilities? Will current U.S. space policy meet the needs of the nation in an era of space globalization? To answer these questions this paper will review the national and military policies on space. It will also summarize the effects of space globalization, to include the world's increasing reliance on civilian space assets. Finally, a strategic analysis of space control policies and doctrine will determine if there is a sound space strategy in the face of globalization and if not, suggest recommendations for possible action.

\section{NATIONAL AND DOD SPACE POLICY REVIEW}

The U.S. National Security Strategy approaches space from the perspective that assets in outer space must be protected. This requires strategic access to space which should be available to all nations, as it is with the global commons of international airspace, open ocean, and cyberspace. Associated with this strategy is the desire to transform our remote sensing, intelligence, and global strike capabilities which would not be possible without space assets. At the same time, our strategy calls for cooperative action with our global partners in terms of regional military alliances and economic policies that will include, "free trade that provides avenues for growth and fosters the diffusion of technologies and ideas that increase productivity and opportunity." At face value this makes good sense. However, the two themes of 
protection of our assets and the promotion of increased opportunity in space for all are not necessarily consistent.

The current National Space Policy, last updated in 1996 with the Clinton administration, recognizes that the U.S. is the world leader in space and must maintain its leadership through a balanced space program, serving our national security, supporting our foreign policy, and stimulating economic growth. "Access to and use of space is central for preserving peace and protecting U.S. national security as well as civil and commercial interests." ${ }^{3}$ In June 2002, President Bush issued National Security Presidential Directive - 15 (NSPD-15), asking the National Security Council (NSC) to review the space policy with a focus on commercial remote sensing, and foreign access to these capabilities. If the old policy was not adequate for today's environment, NSPD-15 directed that a new policy be written. ${ }^{4}$ Output from the council was due by the end of 2003 but is still pending. It remains to be seen if there will be a significant change in policy. The fact that it has been eight years since a rewrite of the national policy has taken place is significant. A lot has happened in the proliferation of space technologies and capabilities during this period.

The national security space guidelines within the National Space Policy state that the United States will conduct those space activities needed for our national security. Those duties are divided into the Defense Space Sector and the Intelligence Space Sector. The Department of Defense (DoD) shall maintain the mission areas of space support, force enhancement, space control, and force application. "Consistent with treaty obligations, the United States will develop, operate and maintain space control capabilities to ensure freedom of action in space and if directed, deny such freedom of action to adversaries." ${ }^{6}$ Likewise, the Director of Central Intelligence must ensure that the intelligence space sector provides timely information and data to support our diplomatic, defense, and economic activities.

To meet national security objectives, the 2004 National Military Strategy is grounded on the principles of protecting the homeland, preventing conflict and surprise attack, and prevailing against adversaries. Securing access to space is an integral part of these tasks, as well as essential to maintaining strategic access and global freedom of action. ${ }^{7}$ In addition, U.S. military strategy recognizes the global proliferation of dual use technologies available to adversaries. This includes information technologies, high resolution imagery, and navigation systems. In future conflicts access to low cost technologies such as these will facilitate possible disruptive and destructive actions by state and non-state actors against U.S. forces and interests.

DoD Space Policy states that space is a medium like land, air, and sea. The ability to access and use space is a vital national interest. Space power is a strategic enabler of the 
National Military Strategy. ${ }^{8}$ It enables information superiority through collection, generation, and dissemination. "U.S. space systems are national property afforded the right of passage through and operations in space without interference. Purposeful interference with U.S. space systems

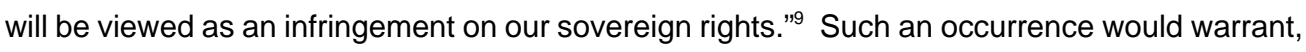
if directed by the President, use of force.

U.S. policy is clearly written, both at the national and military levels. The use of space is vital to preserve peace and promote prosperity. As a world leader the U.S. will take the action necessary to protect space assets, in order to protect vital interests. However, the specifics of how the U.S. will implement space control is left to interpretation. The policy does not say the U.S. will use space weapons. It says the U.S. will develop space control capabilities within treaty guidelines. This subtlety within the documents was probably intentional leaving room for the White House to avoid the issue directly as the DoD implements an aggressive space control strategy. Within the last few years DoD officials have openly talked about the space control strategy and published doctrine on how it will achieve space dominance..$^{10}$ Looking at military doctrine will illustrate how the U.S. is implementing its space control policy. How policy is interpreted and put into action provides an insight into the ability to fulfill its intended purpose.

\section{SPACE CONTROL POLICY IN ACTION}

Joint doctrine for space operations defines space control as, "combat and combat support operations to ensure freedom of action in space for the United States and its Allies and, when directed, deny an adversary freedom of action in space."11 This is divided into four mission areas: surveillance of space, negation, prevention, and protection. Surveillance of space is nothing more than characterizing the space environment by knowing what is in orbit and how it is being used. It is a mission that the remainder of the space control pillars rest upon. Protection is ensuring U.S. and Allied use of space through passive and active defensive measures. Prevention and negation are the space control tasks that focus on denying adversary use of space. Prevention is precluding an adversary's use of U.S. or third party space assets using the range of diplomatic, political, economic, and military measures. ${ }^{12}$ Negation is the denial, deception, destruction, or degradation of an adversary's space capabilities. Achieving space superiority in future conflicts depends on the successful execution of all four space control mission areas. Space superiority cannot be declared if the enemy is using space assets effectively for whatever purpose.

Concerning space weapons, the most recent doctrinal publications are surprisingly open and specific. Air Force Doctrine Document 2-2.1, "Counterspace Operations Doctrine", talks 
about executing anti-satellite operations, possibly preemptively, against military, commercial, or third party satellite systems. This could include operations against the ground segments with conventional kinetic weapons. However, attacking the space segment leaves that controversial concept of space weapons. Joint Publication 3-14, "Joint Doctrine for Space Operations", also provides the option of destroying adversary satellites and space systems. The doctrine of how the military will achieve space dominance is fairly clear. Space weapons will be used to achieve U.S. military objectives. This is not against national policy. As General Lance Lord said in January 2004, "war in space has begun".13 The unclassified documents and candid public dialogue taking place on the subjects of space control and space weapons are having negative effects on our national image and security. The global space community sees the Americans wanting to dominate and exploit space at the expense of others. This is viewed as space imperialism. It is hard to have good international relations with another space power when they know what will be done to their systems in time of conflict. Some space analysts predict an escalation in space weapons development and employment among the major competitors because of the U.S. space control policy. ${ }^{14}$ By providing the public and potential adversaries access to U.S. strategy to conduct space control, the U.S. could be compressing the timelines for adversaries developing cheap and effective space weapons. It is not hard to imagine a competitor thinking that if their space capabilities are going to be neutralized, then they would need to do whatever it takes to destroy the U.S. space capability. The U.S. has much more to lose with its greater reliance on space systems.

Because of the aggressive pursuit of an offensive oriented military space control strategy, commanders must now understand that space operations can affect their decisions. Future Joint Force Commanders must know enemy capabilities and how they are employing space assets or services. They will have to assess a variety of potential political-military situations; all which are applicable today because of the proliferation of space technology in the global financial, transportation, and communications industries. Are third party countries providing the enemy space services and is the U.S. using those same assets? Are the adversary's space assets being used by other third party countries, such as U.S. allies? These are critical questions for the space surveillance realm of space control to answer. Space situational awareness must always be maintained in order to ascertain the enemy's capabilities and intent in space. This is one of the shortcomings of DoD. The Air Force is responsible for monitoring and assessing this battlespace, but continues to misunderstand what type of space intelligence a ground or maritime commander needs. Commanders need to build this space situational 
awareness continuously - in peace and war - in preparation for the time when it will be critical to military (or for that matter, diplomatic) operations. ${ }^{15}$

At present, the Commander U.S. Strategic Command (CCDR USSTRATCOM) is responsible for the space control mission and ensures space superiority for daily global operational commitments. A Joint Force Commander is responsible for ensuring space superiority within a particular theater of operations, however, CCDR USSTRATCOM has Combatant Command of DoD space forces to ensure coordinated global operations. If required, CCDR USSTRATCOM may recommend the transfer forces to another combatant commander for operational control, with Secretary of Defense approval. ${ }^{16}$ There are many issues with the equities of space command, control, and operations support that are beyond the scope of this paper, but it is sufficient to say that space contributes to U.S. global missions and efforts are made to ensure deployed forces are supported.

CCDR USSTRATCOM has agreements in place with commercial, civil, and national space providers because of the increasing reliance on non-DoD systems. For example, $80 \%$ of satellite communications for Operation Iraqi Freedom (OIF) were from commercial systems. ${ }^{17}$ In addition to commercial interaction, USSTRATCOM must deal with agencies like the Department of Transportation who now has responsibility for the Global Positioning System (GPS) constellation. The web of DoD dependency on others is growing as costs to deploy space systems rise. Cost sharing is emerging among U.S. government agencies, just as multinational consortiums are beginning to invest in space.

Why is understanding space strategy important? It is because the U.S. military has faced the effects of space globalization during its most recent operations. The Iraqi forces used commercially available GPS jammers to attempt to deny the U.S. use of precision munitions. With a satellite dish they could monitor the news and the world situation. They were providing interviews to third party news agencies broadcasting via a global space network. ${ }^{18}$ Terrestrial connections to satellite nodes also provide potential adversaries access to global internet and phone services.

Third party space systems are of particular concern to U.S. space planners and operators. The Joint Chiefs of Staff Standing Rules of Engagement, CJCSI 3121.01 clearly identifies the complications of space control in the political-military realm of national policy.

Military or civilian space systems such as communication satellites or commercial earth-imaging systems may be used to support a hostile action. Attacking third party or civilian space systems can have significant political and economic repercussions. Unless specifically authorized by the NCA (President), 
commanders may not conduct operations against space-based systems or ground and link segments of space systems. ${ }^{19}$

This is a good example of the conflict between policy and the realities of executing that policy. Commanders are severely limited in their ability to negate enemy use of space unless they have the time to request approval through the chain of command. The process is very timely. Space control operations at the tactical level inherently have strategic implications.

The conflict between the direction to maintain and deny access at the same time is amplified with space globalization. The U.S. military, as well as the rest of the world, is relying on commercial space assets to disseminate information. DoD space policy addresses cooperation among the intelligence, civil, and commercial sectors to help expand capabilities to focus funding on the appropriate priorities. This means that commercial assets are to be used as much as possible to achieve economies not possible with the current U.S. military space acquisition practices. ${ }^{20}$ This includes both communications bandwidth and imagery. However, the U.S. is not the only one buying services. It is very possible for the DoD to contract the same services and assets allies and adversaries might use. If you deny one party, do you run the risk of denying yourself? A range of diplomatic and technical dilemmas develop quickly. The rapid growth of space globalization has made U.S. space policy difficult to implement. An understanding of space globalization is required in order to determine if current U.S. policy is serving the nation's interests.

\section{SPACE GLOBALIZATION}

The United States and the rest of the world is growing more reliant on space. Because of this, U.S. policy-makers must think of space as an integration of available commercial, national, civil, and multinational space assets. ${ }^{21}$ The days of the American-Soviet bipolar national domination of space are over. Despite the U.S. current status as the world leader, the rest of the space-faring world is catching up. As a result, the U.S. must not only think of military threats, but of the economic and diplomatic threats it faces from foreign space systems.

Most countries in the world use a variety of space services to ensure redundant capabilities within their civil, defense, and industrial sectors. India is one example of the support for multinational space services. They have invested in both the Russian GLONAS and European Union's Galileo navigation systems. Multipolar space systems are one way to ensure a robust access to space. ${ }^{22}$ Assured access to space means money continues to flow through the economy; the military operates at peak efficiency; and political influence can be levied as needed. 
An example of the political and economic power space provides nation states is the recent global competition in satellite navigation. The European Space Agency (ESA) is working to increase its market share in the satellite industry. Its premier effort is the ESA satellite navigation program, Galileo. ${ }^{23}$ There are a number of technical issues between Washington and the ESA concerning interference with the U.S. GPS. The ESA has no doubt that the problems can be worked out. However, any doubt that the ESA would abandon their program due to U.S. objections was dismissed when French President Jacques Chirac commented that failure to proceed with the program would be equivalent to Europe becoming a vassal of the United States. ${ }^{24}$ This highlights the fact that nations view space power as important. It is a reflection of their technological capabilities which translates into a national pride. China's success at putting a man in space brought them into the ranks of the space elite, thus, adding to the influence they can leverage at the economic, military, and diplomatic levels.

The U.S. military is currently the largest buyer of commercial bandwidth in the world. Military requirements vastly exceed the capacity of DoD satellites. During OIF and Operation Enduring Freedom (OEF), 3.2 Gigabytes per second of commercial bandwidth was provided simultaneously to both operations areas in May 2003...$^{25}$ On the positive side of this commercial dependency, DoD demand for satellite communications is relatively small compared to the global commercial supply. ${ }^{26}$ In terms of preference, the DoD prefers to use international systems with at least some U.S. ownership. The primary international communication satellite systems today are INTELSAT, New Skies, PanAmSat, Orion, and Columbia. These systems provide global coverage as currently deployed. The capacity of these systems has grown by seven percent per year and the DoD demand projected in the Emerging Requirements Database through 2006 (at the time of this report) could easily be met. ${ }^{27}$ The growing investment in commercial satellite communications from the DoD and other international customers is fueling investments in increased capacity. In the case of satellite communications the trend in globalization has helped the U.S. military through its insatiable demand for bandwidth. However, the U.S. is not the only one relying on the systems mentioned above. Therein lies the potential conflict in controlling access to satellite communications. The U.S. is using the same systems that it might want to deny access to by others. Usually, there will be many international users of a single satellite, multiplied many times through the system constellation.

Access to commercial imagery is what most people think of in terms of a threat to our National Security. In 1986 the French Satellite Probatoire pour l'Observation de la Terre (SPOT) system became the first commercial imagery system to provide products for a fee. ${ }^{28}$ 
The U.S. commercial system IKONOS became the first one-meter resolution provider in $1996{ }^{29}$ Russia, India, China, and Japan currently have their own space imaging capability. Turkey, South Africa, and the six nation Gulf Cooperation Council are in the process of developing their own assets to be operational by the end of the decade.$^{30}$ Where once America was the sole power in space imagery, global economic needs in urban planning, agriculture, mapping, and telecommunications have resulted in the proliferation of commercial space imaging technology to the rest of the world.

Technology is making access to space imagers easier. Internet services now allow remote purchasing, tasking, and receipt of products. One current example is the Israeli built, Cyprus based ImageSat Corporation satellite. This system allows a customer to directly task a satellite camera and download the image in complete secrecy. Even the company does not know who does the buying or what was bought. ${ }^{31}$ Space systems like these which are easy to use at a reasonable cost will attract many customers, hostile or friendly.

The prevention of this type of space access is problematic for U.S. policy. U.S. policy is to control access, but currently there is no U.S. version of "shutter control" through diplomatic means. Shutter control is a policy the government can use to shut down or limit the areas of collection provided by U.S. licensed imagery companies, in the interests of national security. This is implemented by the Secretary of Commerce after coordination with the Secretary of Defense and Secretary of State. ${ }^{32}$ Disagreements between the cabinet members are resolved by the President. If a combatant commander were to consider shutter control actions, he must be aware of the political and economic implications of such a request. To date, shutter control has never been implemented in the U.S. Even if it were to be considered in future events, it only applies to U.S. licensed companies. Foreign space imagery providers are not affected by U.S. policy and can sell their products to anyone.

At best U.S. policy-makers might try to encourage a type of international shutter control through a diplomatic engagement of a country providing space services to an adversary. This takes political capital and friendly relations with the third party country. The situation is complex and requires specific intelligence on who is doing the buying and where they are conducting their operation. It is easy to think that Iranian intelligence will pick up the phone in Tehran and place their order for overnight delivery from a commercial vendor, but more than likely an individual placed in a strategic location will buy something in a third party country and disseminate the product using any number of wideband communication services. The U.S. attempted to prevent Taliban and Al Qaeda access to high resolution commercial imagery by buying all Afghan imagery from IKONOS during OEF and applying pressure to the French 
Defense ministry on SPOT. ${ }^{33}$ But what about non-U.S. firms? The government can easily ask an American company to comply out of its patriotic duty. In an extreme circumstance a U.S. company can be shut down because they have a license that can be withdrawn. However, there are many other international sources for the same product. If the U.S. has been reluctant to use diplomatic efforts (prevention), then why would it think that using military power (denial) is more likely? The proliferation of space technology is compounding this problem for future conflicts.

The competition other nations are exerting on U.S. strategic space interests and the U.S. commercial space industry is problematic for U.S. space policy. Access to imagery and communications is growing on the national market. This means the military must grow its capabilities to assure and deny access, while at the same time the industrial base must be allowed to compete with its foreign competitors for market share. The 1996 National Space Policy wisely promulgated the decision to augment U.S. military space imagery and communication needs with U.S. commercial sources. U.S. demand for high resolution imagery exceeds the government supply, but more importantly, if a U.S. company did not invest in this area the U.S. would see the migration of its technological edge and space commerce towards other countries. This is another example of how national economic decisions are affecting the ability of the U.S. military to keep up with its own policy.

\section{SPACE POLICY ANALYSIS}

\section{ENDS}

The U.S. objective, as stated in the National Space Policy, is to maintain a global leadership role in space and support a stable national space program that serves the country's interests in the national security, diplomatic, economic, environmental, and scientific arenas. To meet the national intent, DoD policy declares space a vital national interest and an enabler of its overall national military strategy. An attack on U.S. space assets is an attack on American sovereign rights, as well as an asymmetric attack on its ability to project offensive military power.

Overall, what the nation needs is to be consistent with the current policy. Freedom of action in space is required. This meets the requirement for America to be secure while maintaining global leadership and promoting economic growth abroad. It is more a question of how the policy will be implemented. U.S. military doctrine clearly states what will be done to achieve space dominance. However, is this strategy the best course of action for the nation? Focusing on the national security implications of space control, U.S. military and national 
security policy-makers must come to agreement on the ways and means of the stated objectives.

WAYS

Julian Corbett, an early $20^{\text {th }}$ century English maritime strategist whose theories on combined land-sea operations are still applicable today, had a good analogy. It relates to the use of the seas. Does the Navy want to command the seas or just secure right of passage? Corbett argued that the seas are so vast that a ship has many routes to accomplish its task. ${ }^{34}$ In those days you could only find a ship by getting within visual distance. Now there are a variety of remote sensing capabilities to find large objects on any point on the earth, but still to this day it is difficult to find a particular ship among the thousands. The same can be said of space. Is it U.S. policy to command space or be able to secure U.S. passage? As written, the National Space Policy is one of securing passage, however, the U.S. military strategy to implement that policy is one of command. ${ }^{35}$ When planning for a regional conflict the military commander wants to command that air and space above the operation. That means controlling who operates within that space and taking offensive action against anything that can affect friendly military operations. The U.S. military space control strategy is also heavily oriented towards denial rather than prevention. This seems to be happening because prevention is becoming too hard to execute in the face of space globalization. Technology is proliferating to the point where users of laptops with internet access can access commercial space assets. The military has chosen the path of space weapons and technical domination because hard power is becoming the only feasible option to control space.

Washington's clearly stated policy is to protect and defend access to space. Access to and use of space is central for preserving peace and protecting U.S. national security, as well as civil and commercial interests. Within the policies there are a range of options to deal with threats, from diplomatic to military. Maybe the future emphasis should be on the diplomatic and economic power space provides. If space became a free market zone and the regulations on the proliferation of certain technologies were lifted, the U.S. space industry might be able to expand current market share. U.S. satellite manufacturing accounted for $\$ 18.3$ billion (22\%) of total commercial space revenue in $2000 .^{36}$ Is this going to grow as competition with the European consortiums increases? Probably not with the current policy that limits export of critical space technologies.

In the case of commercial remote sensing, the U.S. policy is to encourage the competitive stance of industry to compete in the international environment. The government will rely on 
commercial assets to satisfy its needs and provide an agreeable licensing environment for exports of remote sensing products and space systems. ${ }^{37}$ However, the bureaucracy of licensing and the requirement for national security sometimes run contrary to U.S. industry's ability to compete on the international scene. A recent example is the French government's future dual-use Pleiades high-resolution optical imaging satellites, to be built by EADS Astrium and Alcatel Space. In September 2004, the French government decided it was not worth limiting system capability to that of America's list of satellite technologies requiring special export licenses. ${ }^{38}$ The Pleiades .7 meter resolution imaging system will have a dual military and commercial mission, and will not contain any U.S. manufactured parts. Export regulations and policies like shutter control affect the U.S. market, but the international community is developing its own national or multinational space systems. Washington's ability to control high resolution remote sensing data is quickly eroding as new international systems are deployed.

I would argue that if U.S. market share decreases, the threats to national security increase. Likewise, if U.S. market share increases, the threats decrease proportionally. The U.S. policy of controlling critical space technologies is limiting the abilities of U.S. manufacturers to invest in research and development, as the cash is flowing to foreign competitors. Foreign manufacturers are increasing their parts quality, reliability, and overall system capabilities. This is to the detriment of the U.S. space industrial base and overall national security as U.S. manufacturers slowly lose their technical dominance to a rapidly spreading global space industry.

Diplomatically, the strength of the U.S. space industry is needed to provide an opportunity for America to increase its soft power with the rest of the developing world. With the ability to provide struggling and growing democratic nations the access to space services, the U.S. may help them develop a vibrant economy. This would be a strong diplomatic tool. More importantly, it meets a U.S. strategic objective of maintaining world leadership in technology and enhances the nation's overall economic well being. Will other nations fill this gap for the developing world as U.S. policy limits its ability to maintain technological dominance?

The U.S. National Space Policy must address this issue. Will the U.S. rely on technical domination, which implies a sort of unilateral approach to protecting our own interests? The recent declines in U.S. space manufacturing indicate that trying to protect critical technologies in order to maintain technical domination are having serious consequences for the future of the U.S. space industry. ${ }^{39}$ Or will a multilateral approach be pursued with the other space-faring nations to assure freedom of action in space for all? This might provide the U.S. manufacturers the business needed to maintain their dominance while at the same time providing the 
government the ability to execute space diplomacy and exercise a greater degree of soft power. $^{40}$

\section{MEANS}

Is the U.S. space community organized for success? A major issue is the imbalance of importance placed on space between the national policy side of the government and the military. Space wings, squadrons, and teams are deployed globally at the ready to respond and support the combatant commanders. There are also a significant number of space officers assigned to the Joint Staff and all the Service Staffs within the Pentagon. During OIF alone there were over 600 space personnel deployed in theater. ${ }^{41}$ The National Science and Technology Council is the forum for national space policy. Unfortunately, the lack of staff support has left space issues to be dealt with in a crisis mode only. ${ }^{42}$ The one staff position on the NSC to handle space issues along with the Assistant Director for Space and Aeronautics in the Office of Science and Technology Policy is not sufficient to implement national space policy according to the 2001 Space Commission Report. This lack of leadership at the national policy level could be driving the space community towards military options. While the U.S. is prepositioning itself for military action in space, these activities are not necessarily consistent with the current stated policy.

The brief American history in space began with a model of unilateral action and technical domination. President Kennedy, upon taking office, asked the commitment of the United States to go to the moon. ${ }^{43}$ This was considered to be a matter of national pride, not to mention the international recognition it would bring as the U.S. would demonstrate superiority in technology to the Soviets. This policy of unilateral action and striving for technical superiority was successful. America became dominant in space and that momentum forty plus years ago continues today. However, the leadership gap the U.S. holds is shrinking and there are many more countries and companies in space. The U.S. policy-makers must ask themselves, in the current state of space globalization, if a policy of world leadership and domination in space technology can withstand the commitment that implies. Significant government investments will continue to be needed in order for American corporations to survive international competition. The financial means to maintain leadership in space will be challenged as the global war on terror continues to draw funding away from R\&D budgets. The U.S. will always do what it takes on a unilateral basis to protect national interests, but with the growing costs to maintain global leadership in space America might find itself seeking more multilateral space programs. 
The American history of multilaterism is long and successful. The U.S. seeks alliances and cooperation in everything from international trade (i.e. World Trade Organization) to the conduct of war when the world's interests are at stake (i.e. the international coalition developed for Desert Storm and OEF). The International Space Station (ISS) is one example future U.S. space policy might follow in order to share operational and financial risk. ISS draws upon the scientific and technological resources of 16 nations: Canada, Japan, Russia, 11 nations of the European Space Agency and Brazil. ${ }^{44}$ It is hard to say if the U.S. taxpayer would have been willing to foot the bill alone on such an ambitious endeavor. A future U.S. space policy will probably benefit from similar multinational efforts in the areas of communications, navigation, and remote sensing.

Obviously, adversary acquisition and use of space imagery, space navigation aids, and space communications is of immediate concern to U.S. military planners. Current policy is to prevent and deny enemy access. Is this realistic in today's rapid proliferation of space technology and its integration with the global grid? Maybe U.S. policy-makers should be thinking strategically, recognizing the ease of use of space and instead be cognizant of economic and diplomatic means. Being quicker and better with the operational use of space must always be the primary focus of a warfighter, but U.S. military planners and operators must also be aware of the global environment and the dynamics that affect U.S. interests.

With capabilities growing in Europe, India, China, and the Middle East, the U.S. must ask itself what the appropriate response is to proliferation of space technology in the age of global communications, the internet, professional societies, and advanced education? The realm of space physics and engineering does not stop at the borders of America. It is only a matter of time before technology allows others to do what would not have been imagined just a few years ago. The technical gap that once existed between America and the rest of the world is shrinking. America will always strive to keep ahead, but strategic planning at the national level must continue to think of diplomatic and economic means of controlling space when needed.

The technical means to overcome some of these concerns in U.S. military space strategy depends significantly on the current DoD transformation efforts. ${ }^{45}$ The DoD is seeking to enhance the survivability of its space systems in order to support communications requirements and weapons systems that rely on positioning and timing data. It is fair to say that there can be no global net-centric-warfare capability without space. The rest of the world is also becoming more reliant on space technologies and getting smarter on the inherent vulnerabilities. Electrooptical surveillance, jamming devices, lasers, micro-satellites, and launch services are available to anyone with the funding. For this reason, the current military strategy to dominate space by 
offensive and defensive means will create a competition among space powers. If the U.S. is to stay ahead of the competition it must speed up space transformation efforts with the funding to match.

\section{RECOMMENDATIONS}

A new National Space Policy is needed with the following changes: 1) reword the current policy to emphasize the diplomatic and economic benefits space will provide the nation and the global community; 2) remove the statements of space control and classify that portion of the policy; 3) remove or decrease the limitations on critical space technologies; 4) embrace the concept of multinational space system development in the areas of communications, navigation, and remote sensing; and 5) state the requirement for space leadership within a national space organization that will define space as a vital national interest and begin to develop strategies consistent with the growing technology, economic, military, and political trends. These recommendations are in line with the U.S. National Security Strategy to encourage global economic development, thereby, increasing U.S. investments, interests, and technologies in space to the advantage of the United States. The U.S. space industrial base needs a boost in foreign revenues if it is to maintain its technological edge to the advantage of our national security. An open policy of space control, with the military pursuing a strategy of space domination and space weapons, is reinforcing the growing negative image of the American imperialist cowboy. Competitors are positioning themselves to counter U.S. space control efforts because of the heated public debate this strategy has created. America must be ready to assure space access, but throwing that out in front of the international community is not supporting U.S. national interests. Good international relations are hard enough to maintain. All aspects of space control (policy, doctrine, strategy) should be classified. It is better to let others guess what might be going on, rather than telling them what will be done.

The Space Commission Report issued in May 2001 recognized U.S. growing dependence on space and the vulnerabilities that it creates. It recommended that the U.S. government arrange itself to meet the national security needs of the twenty-first century. ${ }^{46}$ This called for an investment in people. To date only the military has taken aggressive action to meet this requirement. Washington needs the national security apparatus to do the same in order to achieve a balanced approach to space policy.

\section{CONCLUSION}

America's national and military policies for space are clear. The U.S. is relying on space to secure its national interests. Freedom of action in space must be maintained to meet the 
nation's diplomatic, military, and economic needs. Space superiority is achieved through a balanced program of investments in science and technology. As U.S. capabilities grow, so do those of the rest of the world. With this growing dependence comes a proliferation of space technology that makes access for future adversaries increasingly easier. U.S. civil, military, and commercial systems also become more vulnerable.

The current space policies and strategies do not adequately address the international realities of space. Washington wants to control access to space, but it is getting harder to do so when all the nations of the world are clamoring to use commercial space services that are available from multinational corporations and consortiums. The world's growing reliance on space is making it harder to track the users of its systems and services. The current U.S. strategy for dealing with space access is predominately a military option. The DoD is organizing itself to execute a space control strategy. However, the national security policy-makers have no equivalent structure to ensure diplomatic and economic measures are considered. This has created strategic issues for DoD space planners and operators, in the face of technology proliferation, that will create policy dilemmas during a future crisis.

The National Space Policy needs to more accurately reflect the global trends in space utilization. As written, it meets the needs of the nation. However, the strategy to implement the policy is flawed. This highlights the pressing requirement for leadership within the national security space structure to address the growing national interests in space. Warfare has changed throughout history in the mediums of land, sea, and air with new technology. There is now the emergence of space warfare, in existence since the competition with the Soviets started in the late 1950's. America's military space capabilities will continue to be needed, but it must never lose sight of the opportunities to expand diplomatic space power to help deter future conflict, as well as promote global economic growth.

WORD COUNT=6551 


\section{ENDNOTES}

${ }^{1}$ George w. Bush, National Security Strategy 2004, (Washington, D.C.: The White House, 2004), 30.

${ }^{2}$ lbid., 17.

${ }^{3}$ The White House. National Science and Technology Council, National Space Policy, 19 September 1996, 1.

${ }^{4}$ George W. Bush, National Space Policy Review, National Security Presidential Directive/NSPD-15, 28 June 2002, 1.

${ }^{5}$ Definitions for space support, force enhancement, space control, and force application are found in Joint Pub 3-14. Space Control is divided into four mission areas: surveillance of space, negation, prevention, and protection. Prevention and negation are the space control tasks that focus on denying enemy use of space. Space support operations consist of those things like space launch capabilities, mission operations, and recovery operations. Force Enhancement is comprised of the functional areas of ISR, integrated tactical warning and assessment, environmental monitoring, communications, and position/timing/navigation. Space force application refers to the employment of force through systems operating through or from space.

${ }^{6}$ The White House. National Science and Technology Council, National Space Policy, 19 September 1996, 5.

${ }^{7}$ Joint Chiefs of Staff, National Military Strategy of the United States of America 2004 , (Washington, D.C.:U.S. Joint Chiefs of Staff, 2004), 1.

${ }^{8}$ Secretary of Defense Richard Cohen, "Department of Defense Space Policy," memorandum for the Secretaries of the Military Departments, Washington D.C., 9 July 1999, 2.

${ }^{9}$ lbid., 3.

${ }^{10}$ Theresa Hitchens, "National Space Policy: Evolution by Stealth?," Arms Control Today, (Nov 2004): 19.

${ }^{11}$ Joint Chiefs of Staff, Joint Doctrine for Space Operations, Joint Pub 3-14 (Washington, D.C.:U.S. Joint Chiefs of Staff, 9 August 2002), IV-5.

12 Ibid., IV-7.

${ }^{13}$ Hitchens, 19.

${ }^{14}$ Michael Krepon, "Weapons in the Heavens: A radical and Reckless Option," Arms Control Today, (November 2004): 15.

${ }^{15}$ Comments from the Marine Corps Space Integration Branch, Major Steve Redifer, U.S. Marine Corps Space Operations Officer, 12 November 2004. 
${ }^{16}$ Department of the Air Force, Counterspace Operations, Air Force Doctrine Document 22.1 (Washington, D.C.: U.S. Department of the Air Force, 2 Aug 2004), 9.

17 Jeffrey Lewis, "U.S. Space Operations in the International Context," Dwight D. Eisenhower National Security Series, The Eisenhower Institute, (February 2004): 5.

${ }^{18}$ Lewis, 1

19 Joint Chiefs of Staff, Standing Rules of Engagement, Chairman Joint Chiefs Staff Instruction 3121.01A (Washington, D.C.:U.S. Joint Chiefs of Staff, 15 Jan 2000).

${ }^{20}$ Cohen, 3 .

${ }^{21}$ Dale L. Hayden, "The International Development of Space and Its Impact on U.S. National Space Policy," Air Power Research Institute, (Aug 2004): 31

${ }^{22}$ Lewis, 6.

${ }^{23} \mathrm{http}$ //europa.eu.int/comm/space/programmes/galileo en.html. Galileo space system is described on the ESA policy web site. Managed and controlled by civil players, this future European satellite radionavigation system is set to be open, global and fully compatible with the GPS, while offering its users a precision in the range of $5 \mathrm{~m}$ - to $10 \mathrm{~m}$ compared to $70 \mathrm{~m}$ for the GPS. It will use a constellation of 30 satellites in medium orbit (23000 km altitude) linked to a network of terrestrial command stations required for the provision of services.

${ }^{24}$ Hayden, 21.

${ }^{25}$ Lewis, 1.

${ }^{26}$ Tim Bonds, Michael Mattock, Thomas Hamilton, Carl Rhodes, Michael Scheirn, Philip Feldman, David Frelinger, Robert Uy, Employing Commercial Satellite Communications, Project Air Force, RAND, 2000: 27.

27 Ibid., 32.

${ }^{28} \mathrm{http}: / /$ www.spotimage.fr/html/_167_171_336_.php. The SPOT system and the price list for imagery can be found on their home web site.

${ }^{29}$ Steven Livingston and W. Lucas Robinson, "Mapping Fears: The Use of Commercial High-Resolution Satellite Imagery in International Affairs," Astropolitics, Volume 1, Number 2 (Autumn 2003): 6.

${ }^{30}$ Lewis, 6.

${ }^{31}$ Lewis, 7.

${ }^{32}$ Michael R. Hoversten, "U.S. National Security and Government Regulation of Commercial Remote Sensing From Outer Space," The Air Force Law Review (2001): 273.

${ }^{33}$ Livingston and Robinson, 12. 
${ }^{34}$ John Gooch, "Maritime Command: Mahan and Corbet," in Seapower and Strategy, ed. Colin S. Gray \& Robert Barnett (United States Naval Institute, 1989), 33.

${ }^{35}$ AFSPC doctrine is already talking in terms of space superiority, space supremacy and a space combat command. Hence, their use of the terms Offensive Counterspace and Defensive Counterspace - these parallel the doctrinal terms we use to describe air power. Definitions can be found in AFDD 2-2 and AFDD 2-2.1.

${ }^{36}$ Hayden, 22.

${ }^{37}$ George W. Bush, US Commercial Remote Sensing Space Policy (Washington, D.C.: The White House, 13 May 2003).

${ }^{38}$ Warren Ferster, "French Imaging Satellite to be built Sans U.S. Components," Space News, 1 October 2004, 12.

${ }^{39}$ Center for Strategic and International Studies Technology Program Report, "Technology and Public Policy Program, Regulating Satellite Exports," (2003): Chapter 3.

${ }^{40}$ Stephen N. Whiting, "Space Diplomacy: A new Tool for Leverage," Astropolitics, Volume 1, Number 1, (Summer 2003): 74.

${ }^{41}$ The author was the leader of the Joint Space Support Team deployed forward with CENTCOM during OIF. In this position the JSST was responsible to coordinate all space operations and teams deployed throughout the theater. That number was well over 600. Most people don't realize the integration of space and operations that has taken place in the last 3 years. Space is not just an intelligence issue. A lot of $\mathrm{C} 2$ issues need to be worked out, however, the ground, special operations, maritime, and especially the air component commander realize how important it is to have space professionals to enhance their operational capabilities.

${ }^{42}$ Space Commission, Report of the Commission to Assess United States National Security Space Management and Organization, (Washington D.C.: U.S. Space Commission, 11 January 2001): 50.

${ }^{43}$ Walter A. McDougal, ... the Heavens and the Earth, (New York: Basic Books, Inc., 1985), 8.

${ }^{44}$ International Space Station web site, http://www.shuttlepresskit.com/ISS_OVR/

${ }^{45}$ Department of Defense, Transformation Planning Guidance, April 2003, 11.

${ }^{46}$ Space Commission, Report of the Commission to Assess United States National Security Space Management and Organization, (Washington D.C.: U.S. Space Commission, 11 January 2001): 99. 


\section{BIBLIOGRAPHY}

Bonds, Tim, Michael Mattock, Thomas Hamilton, Carl Rhodes, Michael Scheirn, Philip Feldman, David Frelinger, and Robert Uy. Employing Commercial Satellite Communications. Project Air Force, RAND, 2000.

Bush, George W. National Security Strategy 2004. Washington D.C.: The White House, 2004.

Bush, George W. National Space Policy Review. National Security Presidential Directive/NSPD-15, Washington D.C.: The White House, 28 June 2002.

Center for Strategic and International Studies. Technology and Public Policy Program, Regulating Satellite Exports. Washington, DC.: Center for Strategic and International Studies, 2004.

Cohen, Richard, Secretary of Defense. "Department of Defense Space Policy." Memorandum for Secretaries of the Military Departments. Washington, D.C., 9 July 1999.

Department of Defense. Transformation Planning Guidance. April 2003.

Department of Defense. Acquisition of National Security Space Programs. Report of the Defense Science Board Joint Task Force, May 2003.

Department of Defense. Joint Space Control Operations - Negation, Program Test Plan, April 2004.

Department of Defense. National Security Space Acquisition Policy. SAF/USA Number 03-01, Washington D.C.: U.S. Department of Defense, 6 October 2003.

Dolman, Everett C. Astropolitik - Classical Geopolitics in the Space Age. London: Frank Cass Publishers, 2002.

Ferster, Warren, "French Imaging Satellite to be built Sans U.S. Components." Space News, 1 October 2004.

Gooch, John. "Maritime Command: Mahan and Corbet", In Seapower and Strategy, ed. Colin S. Gray and Robert Barnett, United States Naval Institute, 1989.

Hayden Dale L. "The International Development of Space and Its Impact on U.S. National Space Policy." Airpower Research Institute. Research Paper 2004-01.

Hitchens, Theresa. "National Space Policy: Evolution by Stealth?" Arms Control Today, (Nov 2004).

Hoversten, Michael R. "U.S. National Security and Government Regulation of Commercial Remote Sensing From Outer Space." The Air Force Law Review, (2001).

Information Office of the State Council of the People's Republic of China. "China Space Activities." White Paper, 6 Aug 2004. 
Joint Chiefs of Staff, National Military Strategy of the United States of America 2004, Washington D.C.: U.S. Joint Chiefs of Staff, 2004.

Joint Chiefs of Staff, Standing Rules of Engagement, Chairman Joint Chiefs Staff Instruction 3121.01A, Washington, D.C.: U.S. Joint Chiefs of Staff, 15 Jan 2000.

Joint Chiefs of Staff. Joint Doctrine for Space Operations. Joint Pub 3-14, Washington D.C.: U.S. Joint Chiefs of Staff, 9 Aug 2002.

Kehler, Maj Gen C.R. Integrating Space for National Security. National Security Space Integration Office, Under Secretary of the Air Force.

Krepon, Michael. "Weapons in the Heavens: A radical and Reckless Option." Arms Control Today, (November 2004).

Lewis, Jeffrey. "U.S. Space Operations in the International Context." The Eisenhower Institute. Dwight D. Eisenhower National Security Series, 24 Feb 2004.

Livingston, Steven and Robinson, Lucas. "Mapping Fears: The Use of Commercial HighResolution Satellite Imagery in International Affairs." Astropolitics, Volume 1, Number 2, (Autumn 2003).

Logsdon, John M. "Reflections on Space as a Vital National Interest." Astropolitics, Volume 1, Number 1, (Summer 2003).

McDougal, Walter A. ... the Heavens and the Earth. New York: Basic Books, Inc., 1985.

National Research Council. Issues and Opportunities Regarding the U.S. Space Program, May 2004.

Naval Network and Space Operations Command. Naval Space Campaign Plan. NAVNETWARCOM Point Paper, 9 Aug 2004.

Office Force Transformation Office of the Secretary of Defense. Operationally Responsive Space - A New and Complementary Business Model. Summer 2004.

Prebeck, Col Steven. “Joint Warfighting Space”, HQ Air Force Space Command, Aug 2004.

The White House. National Science and Technology Council. National Space Policy. 19 Sep 1996.

U.S. Commercial Remote Sensing Space Policy. 13 May 2003.

U.S. Department of the Air Force. Space Operations. Air Force Doctrine Document 2-2, Washington D.C.: U.S. Department of the Air Force, 27 Nov 2001.

U.S. Department of the Air Force. Counterspace Operations Air Force Doctrine Document 22.1, Washington D.C.: U.S. Department of the Air Force, 2 Aug 2004.

U.S. Space Commission. Report of the Commission to Assess United States National Security Space Management and Organization. 11 Jan 2001. 
United States Marine Corps. USMC Capability Paper and Space Priorities. June 2004.

United States Strategic Command. USSTRATCOM Space Control Mission Area Functional Area Analysis Version 0.3. 12 July 2004.

Whiting, Stephen N. "Space Diplomacy: A new Tool for Leverage." Astropolitics, Volume 1, Number 1, (Summer 2003). 
